Ann. Biol. anim. Bioch. Biophys., 1976, 16 (3), 471-478.

\title{
INTERACTIONS OF TESTOSTERONE AND ESTRADIOL WITH THE NEONATAL RAT BRAIN : PROTECTIVE MECHANISM AND POSSIBLE RELATIONSHIP TO SEXUAL DIFFERENTIATION
}

\author{
B. S. McEWEN, I. LIEBERBURG, N. MACLUSKY and Linda PLAPINGER
}

The Rockefeller University,

New York, N. Y. 10021

\section{SUMMARY}

This paper summarizes recent work from this laboratory concerning the interaction of radioactive testosterone and various estrogens with brains of newborn rats. Testosterone- $7-{ }^{3} \mathrm{H}$ is shown to be converted in vivo to estradiol- $7{ }^{3} \mathrm{H}$ and this product is retained by cell nuclei in hypothalamus and limbic structures to a degree which points to the existence of putative estrogen receptor sites in the neonatal brain. This inference has been verified by in vivo studies using ${ }^{3} \mathrm{H}$-estradiol, ${ }^{3} \mathrm{H}$-diethylstilbestrol (DES) and ${ }^{3} \mathrm{H}$-I I $\beta$-methoxy ${ }_{1} 7 \alpha$-ethynyl $17 \beta$-estradiol (RU 2858) Cell nuclear retention of radioactive estrogens is prevented by non-radioactive $17 \beta$-estradiol and I $7 \alpha$-estradiol and by the non-steroidal anti-estrogen $\mathrm{CI}_{62} 8$, and is not significantly reduced by a variety of non-radioactive $5 \alpha$-reduced androgens or by progesterone. Cell nuclear labeling is substantial in hypothalamus, amygdala, preoptic area, and much lower in cerebellum and midbrain and brainstem. Cerebral cortex is noteworthy because it lacks significant aromatization capability and yet retains ${ }^{3} \mathrm{H}$-estrogens in a manner similar in specificity and intensity of labeling to hypothalamus, amygdala and preoptic area. The developmental changes of estrogen binding capacity are described.

The neonatal brain and blood also contains another estrogen binding protein (fEBP-fetoneonatal estrogen binding protein) which binds ${ }^{3} \mathrm{H}$-estradiol but to a far lesser extent binds synthetic estrogens like ${ }^{3} \mathrm{H}-\mathrm{DES}$ and ${ }^{3} \mathrm{H}-\mathrm{RU} 2858$. The ability of ${ }^{3} \mathrm{H}$-estrogens to bind in vivo to cell nuclear receptor sites appears to be inversely related to their binding to fEBP. Hence, the protective role for this fEBP against potentially deleterious effects of estradiol-1 $7 \beta$ is strongly supported, and the potential dangers of certain synthetic estrogens are once again demonstrated. The relationship of these results to the process of sexual differentiation is discussed.

\section{INTRODUCTION}

Sexual differentiation of the brains of mammals appears to be mediated by the secretion of testosterone from the testes during a critical period of pre- or early postnatal development (Goy, 1970). This physiological event can be mimiced by adminis- 
tration of testosterone during the critical period to females or to castrated males, and at least in two species, rat and hamster, estrogens are equally, if not more, effective compared to testosterone (PLAPINGER and McEWEN, I976).

The discovery by NAFTOLIN, RYAN and coworkers of brain enzymes capable of converting androstenedione or testosterone in vitro to estrone or estradiol, respectively, raises the possibility that the " aromatization " process may be obligatory, or at least significantly involved, in sexual differentiation (NAFToLIN et al, r97 I REDDY et al, 1974). In order for this to be proven it must be shown on a biochemical level that testosterone is converted in vivo to estradiol and that there are estrogen " receptor sites " in the neonatal brain capable of retaining exogenous or enzymatically-produced estradiol. This paper summarizes recent work from our laboratory demonstrating these two processes in the neonatal rat brain. In addition, we summarize evidence that there is a protective plasma binding mechanism operating to prevent the natural estrogen (estradiol-I 7 ) from exerting deleterious " masculinizing " effects.

\section{CONVERSION IN VIVO \\ OF TESTOSTERONE- $7{ }^{3} \mathrm{H}$ TO ${ }^{3} \mathrm{H}-\mathrm{ESTRADIOL}$}

The in vitro demonstration of aromatization (see above) established that this process is intrinsic to brain tissue, besides occurring in steroid producing tissues and the placenta. Some indication that this process occurs in vivo in the neonatal rat brain may be found in the work of WEISZ and GrBBs (1974). This study was repli-

TABLE I

$H$-estradiol as an in vivo metabolite of ${ }^{3} H$-testosterone in neonatal rat brains

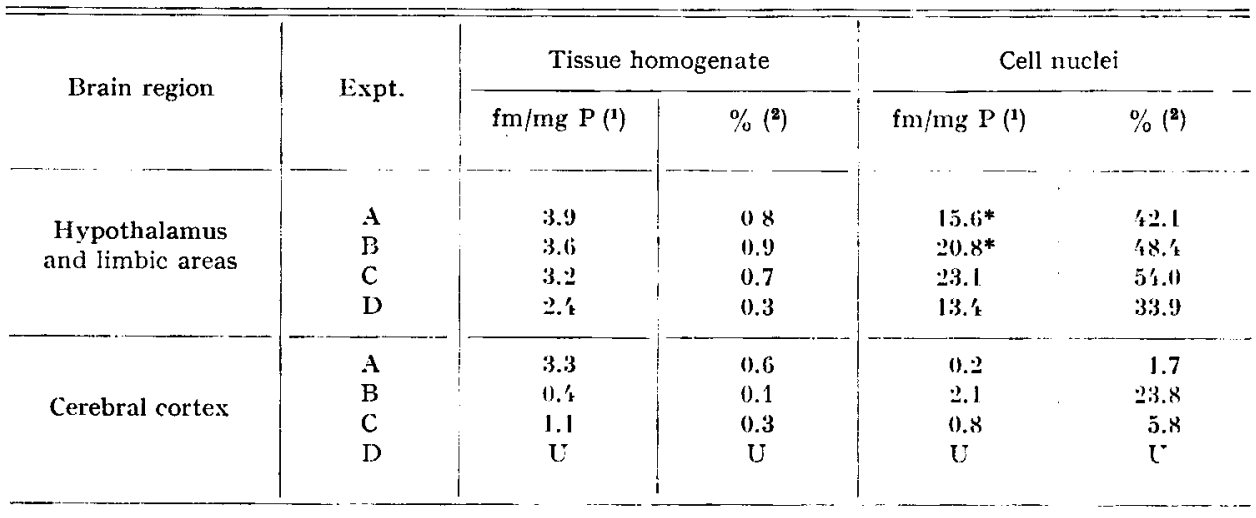

(1) fmoles $\left(10^{-15}\right.$ moles $)$ per $\mathrm{mg}$ protein in that fraction.

(2) Percent of total radioactivity in that fraction.

$\mathrm{U}$ : undetectable levels.

* Concentrations of estradiol, corrected for recovery, determined from final crystallization, were 16.8 and 20.1 fmoles $/ \mathrm{mg} P$ for expts. $A$ and $B$, respectively. Recoveries averaged $5.2 .6 \pm 10.2 \mathrm{p}$. 100 . Data from Lieberburg and McEwen, 1975. 
cated and extended in our laboratory to include an analysis of androgen-derived estradiol in the cell nuclear fraction. Indeed, as shown in table I, 30-50 p. Ioo of the ${ }^{3} \mathrm{H}$-radioactivity in the cell nuclear fraction from a pooled sample of limbic areas (preoptic area, amygdala) and hypothalamus of 5 day old male or female rats was identified by extraction, chromatography, and crystallization as ${ }^{3} \mathrm{H}$-estradiol $\left({ }^{3} \mathrm{HE}_{2}\right)$, whereas cerebral cortex cell nuclei contain very little ${ }^{3} \mathrm{H}$-estradiol (LIEBERBURG and MCEWEN, I975). The high levels of ${ }^{3} \mathrm{HE}_{2}$ in limbic-hypothalamic cell nuclei compared to the lower levels of ${ }^{3} \mathrm{HE}_{2}$ in tissue homogenates indicate an enrichment of $4-7$ fold per unit protein in the cell nuclear compartment, which is comparable to the enrichment seen in limbic cell nuclei of the adult female rat brain after in vivo administration of ${ }^{3} \mathrm{HE}_{2}$ (ZIGMOND and McEWEN, I970). This entichment is indicative of the presence of cell nuclear estrogen receptor sites in the neonatal rat brain. Moreover, this result is consistent with autoradiographic evidence for neuronal retention in hypothalamus, preoptic area, and amygdala of radioactivity injected as ${ }^{3} \mathrm{H}$-testosterone $(\mathrm{T})$ and ${ }^{3} \mathrm{H}$-estradiol, and with the observation that unlabeled $\mathrm{T}$ and $\mathrm{E}_{12}$ both compete for retention of both labeled steroids (SHERIDAN et al., I974 $a, b$ ).

\section{THE DIREC'T DEMONSTRATION OF ESTROGEN RECEP'TOR SITES}

\section{IN NEONATAI, RAT BRAINS}

The above-mentioned success in identifying cell nuclear estrogen receptor sites stands in contrast to earlier failures to demonstrate such sites with doses of ${ }^{3} \mathrm{HE}_{2}$ capable of revealing such sites in adult rat brains (PLAPINGER and McEWEN, I973; see also PLAPINGER and McEWEN, I976). In these studies, regional (i.e., hypothalamic vs. cortex) differences in tissue retention of low doses of ${ }^{3} \mathrm{HE}_{2}$ and cell nuclear retention of ${ }^{3} \mathrm{HE}_{2}$ were not evident until the fourth postnatal week of life. It has become apparent that there are at least two explanations for these earlier results. First, as will be mentioned in the next section, the fetoneonatal estrogen binding protein (fEBP) is apparently able to sequester small to moderate doses of ${ }^{3} \mathrm{H}$-estradiol-I $7 \beta$ and to prevent this steroid by mass action from interacting significantly with its intracellular receptor sites. Second, the cerebral cortex contains some estrogen receptor sites during the first two weeks of postnatal life (see below) and the presence of these sites tends to obscure the regional differences in binding of ${ }^{3} \mathrm{HE}_{2}$ which are seen in the adult rat brain.

Regional cell nuclear binding at postnatal day 3 of high doses (roo $\mathrm{nm} / \mathrm{kg}$ or greater) of ${ }^{3} \mathrm{HE}_{2}$ or ${ }^{3} \mathrm{H}$-DES, is summarized in table 2 . Highest binding is seen in pituitary, followed by hypothalamus, amygdala, cerebral cortex, and preoptic area. Cell nuclear binding in cerebral cortex declines to adult levels during the third postnatal week, whereas binding in other brain regions and in pituitary decreases slightly during this period, and then increases again as the animal approaches adulthood (table 2 and unpublished). The total cell nuclear estrogen binding capacity of pooled hypothalamus, preoptic area, and amygdala (HPA) on day 3 of life is estimated to be one-half of that observed on postnatal day 26 and only one-third of that observed in the adult female rat (unpublished). Cell nuclear binding by HPA as well as by cere- 
bral cortex cell nuclei is blocked by prior injection of a non-steroidal anti-estrogen, CI628 (McEWEN et al., I975), as well as by concurrent injection of unlabeled estradiolI $7 \beta$ and I $7 \alpha$ (unpublished). $5 \alpha$-dihydrotestosterone, $3 \beta$-5 $\alpha$-androstanediol, I9-hydroxy $5 \alpha$-dihydrotestosterone, and progesterone are without significant competitive effect against ${ }^{3} \mathrm{H}$-DES at molar ratios up to 220 times. The relatively greater effectiveness of estradiol-I $7 \varkappa$ as a competitor compared to the $I 7 \beta$-isomer may be related to the inability of the former to bind significantly to fEBP (PLAPINGER et al., I973).

TABLE 2

Regional distribution of cell nuclear ${ }^{3} \mathrm{H}$-estrogen binding sites in brains of immature female rats

\begin{tabular}{|c|c|c|c|c|c|}
\hline \multirow{2}{*}{ Age (days) } & \multicolumn{5}{|c|}{ Cell nuclear retention (fmole/mg DNA) } \\
\hline & Pituitary & Hypothalamus & Preoptic Area & Amygdala & Cortex \\
\hline $2-3$ & $372+46$ & $233+18$ & $101 \pm 1 '$ & $153 \pm 13$ & $121 \pm 16$ \\
\hline $10-11$ & $2892 \pm 289$ & $496 \pm 27$ & $280 \pm 26$ & $278 \pm 23$ & $26 \pm 28$ \\
\hline $25-26$ & $1790 \pm 139$ & $327 \pm 17$ & $337 \pm 27$ & $202 \pm 13$ & $65 \pm 3$ \\
\hline
\end{tabular}

Doses of 100 nmoles $/ \mathrm{kg}$ or greater ${ }^{3} \mathrm{H}$-DES or ${ }^{3} \mathrm{H}-\mathrm{E}_{2}$ injected 2 hours before sacrifice. Nuclear binding sites are therefore at or near saturation.

Otherwise, the distribution and specificity of cell nuclear estrogen retention in the neonatal rat brain are similar to those of a soluble (cytosol) binding protein recently identified by BARLEY and coworkers (1974). This protein, unlike fEBP, exhibits high affinity for the synthetic estrogen RU2858 and sediments in low ionic strength medium at approximately 8 Svedberg units (unpublished), properties shared by cytoplasmic estrogen receptors from the adult rat brain. Furthermore, following in vivo administration of ${ }^{3} \mathrm{H}-\mathrm{RU} 2858$ to neonatal animals, the levels of this cytosol protein are markedly reduced, concomitant to maximal cell nuclear uptake of the labeled hormone (unpublished). Thus, it seems likely that this protein functions as a cytoplasmic receptor for the nuclear binding mechanism.

\section{THE FETONEONATAL ESTROGEN PROTEIN (FEBP)}

AND ITS POSSIBLE PROTECTIVE ROLE

Fetal and neonatal rat blood contains, in abundance, an estrogen binding protein (NUNEZ et al., I97I ; RAYNAUD et al., I97I) which appears to be identical to the alphafetoprotein (URIEI, et al., I972; AUSSEL et al., I973). This fEBP has a sedimentation coefficient in sucrose density gradients of $\simeq 4 \mathrm{~S}$ (RAYNAUD et al., I97I; PLAPINGER et al., r973) and shows a marked preference for estradiol-I $7 \beta\left(\mathrm{E}_{2}\right)$ over synthetic 
estrogens such as diethylstilbestrol (DES) or RU2858 (table 3 ; see RAYNaud et al., I97I ; RAYNAUD, I973; McEWEN et al., I975) in contrast to the neonatal tissue receptor. Thus whereas low doses of ${ }^{3} \mathrm{HE}_{2}$ are largely sequestered by $\mathrm{fEBP}$ and do not reach the cell nuclear receptor sites in significant amounts, comparable doses of the synthetic estrogen ${ }^{3} \mathrm{H}-\mathrm{RU} 2858$ do not bind to $\mathrm{AEBP}$ and do bind to brain cell nuclear receptor sites (table 3 ; see McEWEN et al., I975).

TABLE 3

Relative binding of ${ }^{3} \mathrm{H}$-estrogen to $f E B P$ and to neonatal brain cell nuclear receptors

\begin{tabular}{c|c|c}
\hline \hline & Binding to fEBP & Retention by nuclei \\
\hline & 100 & 1 \\
${ }^{3}$ H-estradiol & 17 & 2.5 \\
${ }^{3}$ H-DES & 1 & 35 \\
\hline
\end{tabular}

Based on McEwen et al., 1975.

The fEBP is also found in cerebrospinal fluid and in washes of neonatal brain tissue and can therefore also be detected in cytosol from neonatal rat brains perfused at sacrifice to remove blood contamination (PI,APINGER et al., I973). This protein is immunochemically similar to fEBP from blood (PL,APINGER and McEiwEN, I975) and its presence in brain interferes with the detection of the true cytosol receptor sites unless one uses special methodological precautions with ${ }^{3} \mathrm{HE}_{2}$ as ligand (BARLEY et al., I974) or uses a synthetic estrogen such as ${ }^{3} \mathrm{H}-\mathrm{RU} 2858$. It remains to be determined whether the presence of $\mathrm{fEBP}$ in brain has any significance besides the protective function ascribed to the blood fEBP (SOLOFF et al., I97I ; URIEL and de NECrAUD I973; Plapinger et al., I973; RAynaud, I973; McEWEN et al., I975).

It may be predicted from the differential binding of ${ }^{3} \mathrm{HE}_{2}$ and ${ }^{3} \mathrm{H}-\mathrm{RU} 2858$ by $\mathrm{fEBP}$ and by brain receptors that the latter would be more effective than $\mathrm{E}_{2}$ in promoting sexual differentiation of the brain. Indeed this appears to be the case, and dramatically so, from recent studies of Doughty et al. (I975). RU2858 is also more effective than $\mathrm{E}_{2}$ in promoting uterine growth in rats during the first two weeks of postnatal life when titers of $f E_{6} B P$ are high and equally effective to $E_{2}$ when fEBP titers are low or undetectable at the end of the third postnatal week of life (RAYNAUD, I973). DES, which is also a poor ligand for fEBP and which therefore binds better than $\mathrm{E}_{2}$ to neonatal brain receptors, is also known to induce brain sexual differentiation (KINCL et al., I965; LADOSKy, I967; CLEMENS, I974).

Deleterious effects of estrogens are not confined to the brain. DES has been shown to induce reproductive tract abnormalities - masculine development of the reproductive tract and increased incidence of primary vaginal carcinoma - in female human children of mothers who received DES during pregnancy (BongroVANNI et al., I959; HERBST et al., I972). 


\section{DISCUSSION AND CONCLUSIONS}

There are now three pieces of evidence pointing to strong involvement of aromatization (conversion of testosterone to estradiol) in the sexual differentiation of the rat brain. First, there is the effectiveness of estrogens as well as of testosterone in "masculinizing " the brain and the ineffectiveness of androgens such as $5 \alpha$-dihydrotestosterone, which cannot be aromatized (for review see PLAPINGER and McEwEN, I976). Second, there is the demonstrated conversion of testosterone- $7-{ }^{3} \mathrm{H}$ to ${ }^{3} \mathrm{H}$ estradiol and the retention of this steroid by cell nuclei in the hypothalamus and limbic areas of the neonatal rat brain. Third, there is the demonstration by autoradiography and by biochemical procedures of cell nuclear and soluble estrogen receptors in neonatal rat brains, with a specificity which parallels the action spectrum, in so far as it is presently known, of steroids in inducing brain sexual differentiation.

Critical experiments in proving that aromatization actually plays an important role in sexual differentiation of the brain would involve either the use of agents which block aromatization or agents which prevent access of estrogen to its intracellular receptor sites. With regard to the former approach, CLEMENS (I974) has reported some success in blocking the masculinizing effects of testosterone given to castrated, newborn hamsters by pentobarbital and SKF $525 \mathrm{~A}$, agents which may cause decreased conversion of the testosterone to estradiol. However, proof of the efficacy of these agents in blocking aromatization is currently lacking. With respect to receptor antagonists, there have been reports of success in preventing " defeminization " of female rats by giving a non-steroidal anti-estrogen, MER-25, together with testosterone propionate (DoughTy and McDonald, I974). There have also been three reports of failures to obtain such a blocking effect by MER-25 (GoTTLIEB et al., I974; Brown-Gran'r, I974; HAYASHI, I974). The reasons for these discrepancies are not clear, but it should be noted that from our own experience and that of others (e.g., RUH and RUH, I974) MER-25 is not a very strong antagonist compared to a number of other antiestrogens. We are presently conducting experiments using the more potent antagonist CI628 in an attempt to achieve a less equivocal proof of the effectiveness of anti-androgen treatment in blocking sexual differentiation induced by testosterone.

It also remains for future work to demonstrate whether aromatization plays a role in sexual differentiation of the brains of other species besides the rat and hamster. Recent work by GoLDFOOT and VAN DER WERFF TEN BOSCH (I975) on the guinea pig would tend to support at least a partial role for aromatization. Moreover, the recent report of ADkINs (I975) with the Japanese quail, indicating the effectiveness of both testosterone and estradiol injected into the egg, in demasculinizing males suggests a possible role of aromatization in this species, for which the chromosomal sex and therefore the hormonally-neutral sex is opposite to that of the mammal. 


\title{
ACKNOWLEDGEMENTS
}

The research described in this report was supported by research grant NSo7o8o and by training grant GMI 789 from the U.S. Public Health Service, and by an institutional grant RF 70095 from The Rockefeller Foundation. The authors wish to thank Ms. Gislaine WaLLACH and Claude Chaptal for their technical assistance and Ms. Winifred Berg for editorial assistance. We would also like to acknowledge the cooperation of Dr. J.-P. Raynaud, Roussel Uclaf, Romaineville, France, for providing us with $\mathrm{RU}_{2} 8_{5} 8$.

\section{RÉSUMÉ}

\author{
INTERAC'TIONS DE LA TESTOSTÉRONE E'T DE L'CESTRADIOL, \\ SUR LE CERVEAU DU RAT NOUVEAU-NÉ: \\ MÉCANISME PROTECTEUR ET INFLUENCE POSSIBLE, \\ SUR LA DIFFÉRENCIATION SEXUEILE
}

Cet article résume nos travaux récents concernant l'interaction de la testostérone et de différents œstrogènes radioactifs sur le cerveau de rats nouveau-nés. La testostérone- $7^{-3} \mathrm{H}$ est convertie in vivo en ostradiol- $7{ }^{3} \mathrm{H}$ qui est retenu dans les noyaux des cellules de 1'hypothalamus et des structures limbiques en telle quantité que cela rend probable l'existence de sites récepteurs aux oestrogènes dans le cerveau néonatal. Cette possibilité a été vérifiée par des expériences in vivo utilisant l'ostradiol- ${ }^{3} \mathrm{H}$, le diethylstilbestrol- ${ }^{3} \mathrm{H}$ (DES) et le I $\beta$-methoxy-I $7 \alpha$-ethynyl-I $7 \beta$ œstradiol- ${ }^{3} \mathrm{H}\left(\mathrm{RU}_{28} 8{ }_{5}\right)$. La rétention nucléaire d'œstrogènes radioactifs est inhibée par l'œstradiol-I $7 \beta$ froid, par l'œestradiol-I $7 \alpha$ and par l'anti-œestrogène CI628 mais n'est pas réduite de façon significative par des androgènes $5 \alpha$-réduits non radioactifs ou par la progestérone. Le marquage radioactif du noyau cellulaire est important dans l'hypothalamus, l'amygdale, l'aire préoptique et beaucoup plus bas dans le cervelet, le mésencéphale et le tronc cérébral. Le cortex cérébral est remarquable car il est pratiquement incapable d'aromatisation, bien qu'il fixe les œestrogènes-3 $\mathrm{H}$ avec la même spécificité et la même intensité que l'hypothalamus, l'amygdale et l'aire préoptique. Les changements de la capacité de fixation des œstrogènes au cours du développement sont décrits. Le cerveau néonatal et le sang contiennent d'autre part une protéine capable de lier l'œstrogène (la protéine fotonéonatale fixatrice d'œstrogènes, ou fEBP). Cette protéine lie l'œstradiol ${ }^{3} \mathrm{H}$ mais beaucoup moins les œestrogènes synthétiques tels que le DES-3 $\mathrm{H}$ et le RU28 $5_{5}^{8-}{ }^{3} \mathrm{H}$. La capacité des œstrogènes- ${ }^{3} \mathrm{H}$ de se fixer, in vivo aux sites récepteurs du noyau cellulair a apparaît être inversement reliée à leur liaison avec la protéine fœtonéonatale. Le rôle protecteur de cette fEBP contre les effets potentiellement nocifs de l'œestradiol-ı $7 \beta$ est ainsi fortement suggéré et les dangers possibles de certains astrogènes synthétiques sont montrés une fois de plus. Le rapport entre ces résultats et le processus de différenciation sexuelle est discuté.

\section{RÉFÉRENCES}

ADKins E. K., I975. Hormonal basis of sexual differentiation in the Japanese quail. J. Comp. Physiol. Psych., 89, 6r-7r.

Aussel C., Uriel J., Mercier-Bodard C., I973. Rat $\alpha$-fetoprotein : isolation, characterization and estrogen-binding properties. Biochimie, 55, I43I-1437.

Barley J., Ginsburg M., Greenstein B. D., Maclusky N. J., Thomas P. J., I974. A receptor mediating sexual differentiation? Nature, 252, 259-260.

Bongrovanni A. M., Digeorge A. M., Grumbach M. M., I959. Masculinization of the female infant associated with estrogen therapy alone during gestation : four cases. J. Clin. Endocr. Metab., 19, I004-IOII.

Brown-Grant K., 1974. Failure of ovulation after administration of steroid hormones and hormone antagonists to female rats during the neonatal period. J. Endocr., 62, 683-684. 
Clemens L. H., 1974. Neurohormonal control of male sexual behavior, 23-53, in : Montagna W., SadLer W. A. Reproductive Behavior, Plenum Press, New York.

Doughty C., MeDonald P. G., 1974. Hormonal control of sexual differenciation of the hypotalamus in the neonatal female rat. Differentiation, 2, 275-285.

Doughty C., Booth J. E., McDonald P. G. Parrott R. F., I975. Effects of cestradiol-I7 $\beta$, oestradiol benzoate and the synthetic oestrogen, RU2858 on sexual differentiation in the neonatal female rat. $J$. Endocr. (in press).

GoldFoOT D. A., FAN DER WERF TEN BOSCH J. J., 1975. Mounting behavior of female guinea pigs after prenatal and adult administration of the propionates of testosterone, dihydrotestosterone, and androstanediol. Horm. Behav., 6, $139-148$.

Gottlieb H., Gerale A. A., Thiel A., 1974. Receptivity in female hamsters following neonatal testosterone, testosterone propionate, and MER-25. Phys. Behav., 12, 6r-68.

GoY R. W., r97o. Early hormonal influences on the development of sexual and sex-related behavior, 196-206, in : Schmidt F. O. (ed.) The Neurosciences : Second Study Program, Rockefeller Univ. Press, New York.

HAYASHI S., 1974. Failure of intrahypothalamic implants of antiestrogen, MER-25, to inhibit androgen sterilization in female rats. Endocr. Jap., 21, 453.457.

Herbst A. L., Kurman R. J., Scully R. E., Poskanzen D. C., I972. Clear-cell adenocarcinoma of the genital tract in young females. N. Engl. J. Med., 287, I259-1264.

Kincl F. A., P A. F., Magueo M., Lasso L. H., Oriol A., Dorfman R. I., I965. Inhibition of sexual development in male and female rats treated with various steroids at the age of five days. Acta Endocr., 49, 193-206.

LADoskr W., I967. Anovulatory sterility in rats neonatally injected with stilbestrol. Endokrinologie (Liepzig), 52, 259-26r.

LIEDERBURG I., McEwen B., I975. Estradiol-I7 $\beta$ : a metabolite of testosterone recovered in cell nuclei from limbic areas of neonatal rat brains. Brain Res., 85, I65-170.

McEwen B. S, Plapinger L., Chaptal C., Gerlach J., Wallach G., I975. Role of fetoneonatal estrogen binding proteins in the association of estrogen with neonatal brain cell nuclear receptors. Brain Res., 96, 400-406.

Naftolin F., Ryan K. J., Petro Z., I97I. Aromatization of androstenedione by the diencephalon. J. Clin. Endocr. Metab., 33, 368-37o.

Nunez E., Savu L., Engelmann F., Benassayag C., Crepy O., Jayle M.-F., I97x. Origine embryonnaire de la protéine sérique fixant l'œstrone et l'œestradiol chez la Ratte impubère. $C$. $R$. Acad. Sci. (Paris) Serie D., 273, 242-245.

Plapinger L., McEwen B. S., I973. Ontogeny of estradiol-binding sites in rat brain. I. Appearance of presumptive adult receptors in cytosol and nuclei. Endocrinology, 98, III9-I 28.

Plapinger L., McEwen B. S., 1975. Immunochemical comparison of estradiol-binding molecules in perinatal rat brain cytosol and serum. Steroids, 26, 255-265.

Plapinger L., McEweN B. S., 1976. Gonadal steroid-brain interactions in sexual differentiation, (in press) in : Hutchison J. (ed.), Biological determinants of sexual behavior J. Wiley, N. Y. and London.

Plapinger L., McEwer B. S., Clemens L. E., I973. Ontogeny of estradiol-binding sites in rat brain. II. Characteristics of a neonatal binding macromolecule. Endocrinology, 93, II29-II39.

RAYNAUD J. P., I973. Influence of rat estradiol binding plasma protein (EBP) on uterotrophic activity. Steroids, 21, 249-258.

Raynaud J. P., Mercier-Bodard C., Baulieu E. E., I97I. Rat estradiol binding plasma protein (EBP). Steroids, 18, 767-788.

REDDY V. V. R., Naftolin F., RYan K. J., I974. Conversion of androstenedione to estrone by neural tissues from fetal and neonatal rats. Endocrinology, 94, II7-121.

RuH T. S., Rvh II. F., r974. Effect of antiestrogens on nuclear binding of estrogen-receptor. Steroids, 24, $209-224$

Sheridax P. J., Sar M., StumpF W. E., I974 $a$. Autoradiographic localization of ${ }^{3}$ H-estradiol or its metabolites in the central nervous system of the developing rat. Endocrinology, 94, 1386-1 390.

Sheridax P. J., SAR M., StumpF W. E., $1974 b$. Interaction of exogenous steroids in the developing rat brain. Endocrinology, 95, 1749-1753.

Soloff M. S., Creange J. E., Potrs G. O., I97I. Unique estrogen-binding properties of rat pregnancy plasma. Endocrinology, 88, 427-432.

Uriel J., de Nechaud B., I973. An outline of the physiopathology of rat $\alpha$-fetoprotein, 35-47, in : HIRAI H., MIYajI T., (eds), Alpha-fetoprotein and hepatoma, University park press, Baltimore.

Uriel J., de Nechaud B., Dupiers M., 1972. Estrogen-binding properties of rat, mouse, and man fetospecific serum proteins. Demonstration by immuno-autoradiographic methods. Biochem. Biophys. Res. Comm., 46, II75-II80.

Weisz J., GibBs C., I974. Metabolites of testosterone in the brain of the newborn female rat after an injection of tritiated testosterone. Neuroendocrinology, 14, 72-86.

ZIGMond R. E., McEwen B. S., I97o. Selective retention of oestradiol by cell nuclei in specific brain regions of the ovariectomized rat. J. Neurochem., 17, 889-899. 